International Journal of Physical Sciences and Engineering
Available online at http://sciencescholar.us/journal/index.php/ijpse
Vol. 2 No. 2, August 2018, pages: $39 \sim 49$
e-ISSN : 2550-6943, p-ISSN : 2550-6951
http://dx.doi.org/10.29332/ijpse.v2n2.142

\title{
Energy Interpretation of Solar Radiation Affects for Artemisa Province
}

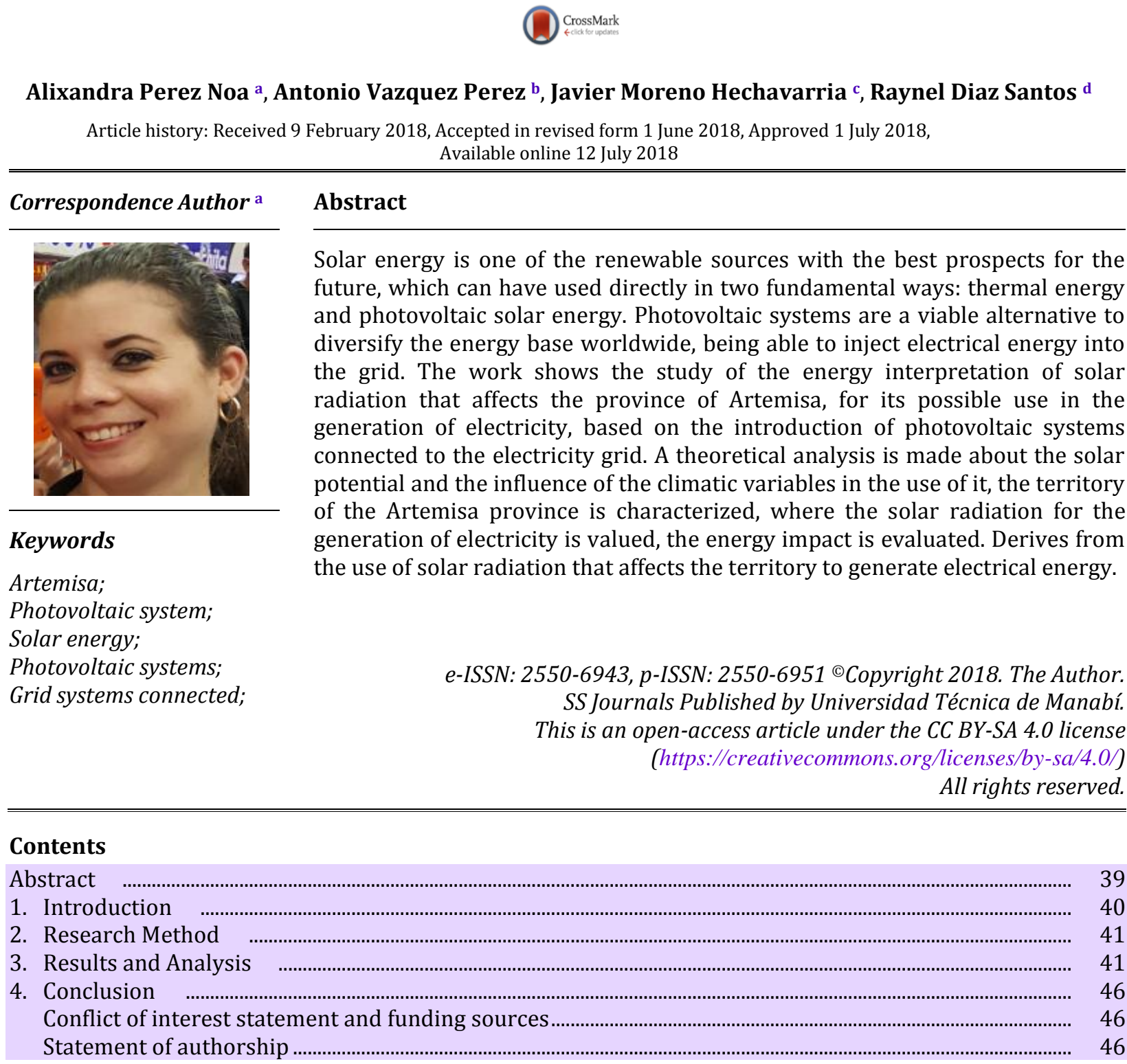

a TRD-Caribe, Energy Group to Havana, Cuba

b Engineering career in constructions, Universidad Técnica de Manabí, Portoviejo, Ecuador

c Construction Company for Works for Tourism (ECOT-Habvana), Havana, Cuba

d Center for Research and Electroenergetic Tests, School of Electrical Engineering, Cujae La Havana, Cuba 


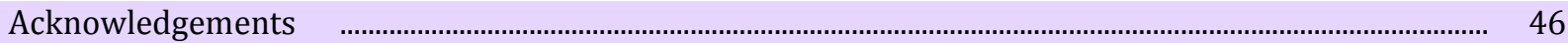

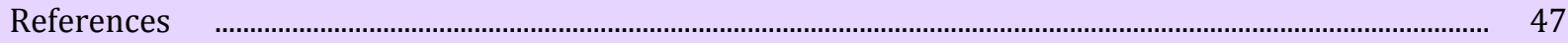

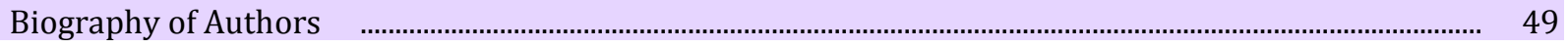

\section{Introduction}

Millions of people living in developing countries do not have access to electricity in their homes. The lighting of the houses, the refrigeration, the possibility of using electrical appliances, constitute a fundamental requirement for progress and comfort in the living conditions of the human being since electric service has become essential for almost all daily activities.

Communities that lack electricity are mostly found in intricate, mountainous places that are difficult to access. In many of these cases, the connection to the electricity grid is an economically unfeasible option, due to the cost of the extension of the technical infrastructure. However, the generation of electricity based on renewable sources of energy becomes a potentially economical and technically viable solution, capable of satisfying the existing demand where the network has not been possible to access [1].

Solar energy is one of the renewable sources with the best prospects for the future, particularly of the nonpolluting group, which is generated by the Sun and is converted energetically by other users through the use of technologies, either for the heating of fluids, drying of products, solar saunas or to generate electricity.

Almost all renewable sources of energy depend on solar activity; but the primary energy of the Sun can be used directly in two fundamental ways: thermal energy and solar photovoltaics [2].

Photovoltaic solar energy is based on the capture of solar energy and its transformation into electrical energy by means of photovoltaic modules [2], and as a renewable source, it means a formula basically more respectful with the environment than conventional energies, because inexhaustible resources are available to cover energy needs. An elementary characteristic is that its application usually takes place at the local level, since the generation of electrical energy can be carried out at the same point where it is consumed, thus preventing losses in the processes of transportation and distribution of electricity [3].

This energy has as many applications as electricity can have. The only existing limitation is the cost of the equipment or the size of the panel field. Among some of its uses we can find: the electrification of rural homes; the water supply to populations; pumping and irrigation of water; livestock ships; electric pastures; telecommunications (signal repeaters); mobile and rural telephony; water treatment (desalination, chlorination); signage (maritime, rail, land and air); Street lighting; connection to the network; cathodic connection; satellite remote control system; and fire detection [4].

The world producers of photovoltaic energy with the greatest installed power are currently: Germany, China, Italy, the United States, Japan, Spain, France, Belgium, and Australia, where China is currently the main producer of photovoltaic solar energy worldwide [5]. In addition, Spain is one of the European countries with higher levels of solar radiation, which has a high potential market for photovoltaic systems connected to the electricity grid [6].

Due to the great solar potential of the Cuban archipelago, the generation of a photovoltaic system in Cuba will produce more electricity than in any of the European countries, since in Germany and the rest of Europe, grid-connected systems substitute energy generated with large hydroelectric plants and nuclear plants in national systems interconnected throughout the continent; in Cuba it would basically substitute low and medium power and efficiency thermoelectric power, which burns fossil fuels for a relatively small and weak, long and narrow system, which would imply an economic advantage [7].

Different experiences have been had in systems connected to the network since 2002, until the year 2012 when one of Santiago de Cuba's $7.5 \mathrm{kWp}$ power was installed, this system is made up of a module of 30 solar panels of $250 \mathrm{Wp}$ each one, connected in series to three inverters, which convert the direct current into alternating current to generate, as expected, about $6.9 \mathrm{kWh}$ a day [8].

The first photovoltaic park in the province of Camagüey, located in the municipality of Guáimaro, was synchronized to the National Electric Power System (SEN) in Cuba in 2012, with a contribution of 1.6 MW / h, which must pay more than 2,500 MWh year, which will mean to stop using more than 600 tons of oil for the generation of electricity [9][13]. 
In view of the economic and social development, territorial ordering and sustainability, the country are governed by what is expressed in the guidelines of the economic and social policy approved in 2011 [10].

The objective of the work focuses on the realization of the energy interpretation of the solar potential incident in the province of Artemisa, from the soil useful to develop investments, using photovoltaic technology for systems connected to the network, and thus increase the use of renewable sources, complying with the energy policy outlined by the country, where the struggle for sustainability must first overcome the use of oil for the generation of electricity.

\section{Research Method}

For the study carried out, the regulations were defined and the methodology developed in Cuba was used to carry out the territorial energetic ordering using the geographic information system (GIS), which allows determining from the territorial planning, the areas that meet the conditions and parameters to be exploited, in the realization of investments for the use of solar radiation with photovoltaic technology.

We used the geoportal located at CIPEL, www.sigfre.edu.cu, which provides information on the diffuse solar radiation of the whole country and on the inclined plane [11][14], PVsoft was used as a virtual tool for the analysis [12][15].

\section{Results and Analysis}

One of the first results obtained was the characterization of the solar radiation for the horizontal plane (direct, diffuse and global) and the solar potential of each one of the municipalities of the Artemisa province. The data shown in the table is based on a 22-year study by the SWERA project. Table 1 shows solar radiation by the municipality.

Table 1

Solar radiation by municipalities

\begin{tabular}{lcccc}
\hline \multicolumn{1}{c}{ Municipalities } & $\begin{array}{c}\mathrm{Idn} \\
\left(\mathrm{kWh} / \mathrm{m}^{2} . \text { día }\right)\end{array}$ & $\begin{array}{c}\mathrm{Id} \\
\left(\mathrm{kWh} / \mathrm{m}^{2} \text {.día }\right)\end{array}$ & $\begin{array}{c}\mathrm{I} \\
\left(\mathrm{kWh} / \mathrm{m}^{2} \text {.día }\right)\end{array}$ & $\begin{array}{c}\mathrm{HP} \\
\left(\mathrm{kWh} / \mathrm{m}^{2} \text {.día }\right)\end{array}$ \\
\hline Güira de Melena & 4,82 & 0,92 & 5,74 & 5,61 \\
Alquizar & 4,79 & 0,34 & 5,13 & 5,61 \\
Bauta & 4,60 & 0,15 & 5,49 & 5,64 \\
San Cristóbal & 4,83 & 0,39 & 5,23 & 5,62 \\
Candelaria & 4,76 & 0,47 & 5,23 & 5,48 \\
Artemisa & 4,62 & 0,95 & 5,57 & 5,49 \\
Bahía Honda & 4,47 & 0,73 & 5,20 & 5,62 \\
S .A de los Baños & 4,60 & 0,63 & 5,23 & 5,63 \\
Caimito & 4,60 & 0,89 & 5,49 & 5,64 \\
Guanajay & 4,52 & 0,71 & 5,23 & 5,63 \\
Mariel & 4,60 & 0,63 & 5,23 & 5,70 \\
Total & 51,26 & 6,81 & 58,77 & 61,68 \\
\hline
\end{tabular}

Where:

Idn $\rightarrow$ Incident normal direct solar radiation.

Id $\rightarrow$ Diffuse solar radiation.

$\mathrm{I} \rightarrow$ Global solar radiation.

$\mathrm{HP} \rightarrow$ Solar potential.

The diffuse radiation for the horizontal plane was calculated indirectly based on experimental measurements of incident direct radiation and global solar radiation. Therefore Id is obtained from the relationship shown in equation 1.

Noa, A., Pérez, A., Hechavarría, J., \& Santos, R. (2018). Energy interpretation of solar radiation affects for Artemisa province. International Journal Of Physical Sciences And Engineering (IJPSE), 2(2), 39-49. 


$$
I d=I-I d n \cdot \cos (\theta z)
$$

Where:

$\theta \rightarrow$ An angle that forms direct solar radiation on a horizontal surface with the normal one.

Table 2 shows the minimum and maximum global solar radiation in the horizontal plane. These data are very important since the most critical potential is elementary when designing an autonomous system that has to satisfy a certain demand, because if the design is carried out by the average, the day that critical potential happens no longer it satisfies the system and it will not be reliable.

Table 2

Minimum and maximum global solar radiation

\begin{tabular}{lcc}
\hline \multicolumn{1}{c}{ Months } & $\begin{array}{c}\text { Imín } \\
\left(\mathrm{kWh} / \mathrm{m}^{2} \text {.día }\right)\end{array}$ & $\begin{array}{c}\text { Imáx } \\
\left(\mathrm{kWh} / \mathrm{m}^{2} \text {.día }\right)\end{array}$ \\
\hline Enero & 3,34 & 4,50 \\
Febrero & 4,37 & 5,39 \\
Marzo & 4,64 & 6,30 \\
Abril & 5,90 & 7,03 \\
Mayo & 5,49 & 7,16 \\
Junio & 5,06 & 6,66 \\
Julio & 5,38 & 6,99 \\
Agosto & 5,56 & 6,52 \\
Septiembre & 4,65 & 6,12 \\
Octubre & 4,15 & 5,56 \\
Noviembre & 3,57 & 4,77 \\
Diciembre & 3,31 & 4,22 \\
Total anual & 4,62 & 5,94 \\
\hline
\end{tabular}

Where:

Imín $\rightarrow$ Minimum global solar radiation

Imax $\rightarrow$ Maximum global solar radiation

The values associated with the incident solar radiation in the province of Artemisa, are optimal to be exploited, both in the generation of electricity, as in thermal systems; but particularly when thinking about the large-scale penetration of photovoltaic technologies through the introduction of systems connected to the network.

In photovoltaic power plants the power depends on the type and quantity of technologies that make up the facilities, so it can be said that to install a $100 \mathrm{kWp}$ photovoltaic power plant, 1,000 photovoltaic modules of $100 \mathrm{Wp}$ are required; but when it comes to estimating the energy that this same power station can generate (specific productivity), then we must first consider the solar radiation that will affect the photovoltaic cells and other indicators among which are: the square meters that they will occupy the cells per $\mathrm{kWp}$; the estimated technical efficiency index for the energy conversion of the technology; and the efficiency of capturing the modules, where the incidence of climatic variables intervenes, mainly the cloudiness, the ambient temperature and the environmental contamination that can have an impact on the dirt on the surface of the modules [12]. Installed power can be calculated using equation 2 .

$$
\mathrm{Ppi}=\mathrm{Cm} \cdot \mathrm{Ppm}
$$

$533 / 5000$ 


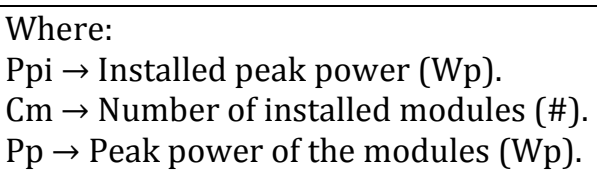

The photovoltaic power plants do not work with fossil fuels, the energy carrier that makes the electrical generation of these technologies possible is solar radiation, which means that the specific productivity (estimated energy that can be generated during a day), in a Photovoltaic power plant based on polycrystalline silicon technology, can be calculated using equation (3).

$$
P e=(P p i \cdot H p \cdot A c \cdot d) \cdot \eta t \cdot \eta c
$$

Where:

$\mathrm{Pe} \rightarrow$ Specific productivity $\mathrm{kWh} / \mathrm{kWp} /$ day.

$\mathrm{Ppi} \rightarrow$ Installed peak power (Wp).

$\mathrm{Hp} \rightarrow$ Solar potential (kWh $/ \mathrm{m}^{2}$.day).

$\mathrm{Ac} \rightarrow$ Area of the capture of the cells $\left(6.4 \mathrm{~m}^{2} / \mathrm{kWp}\right)$.

$\mathrm{d} \rightarrow \quad$ Generation time of the photovoltaic power station (1 day).

$\eta t \rightarrow$ Nominal technical efficiency of the modules (14/100 for the polycrystalline silicon that is commercialized in Cuba).

$\eta c \rightarrow$ Efficiency of uptake of radiation by photovoltaic cells $(85 / 100$ in the environmental conditions of Cuba).

The constant variations in the concrete results of the photovoltaic generation, which are given by the natural behavior of the Sun in its apparent movement in the ecliptic, implies that every day and month of the year there is a differentiated behavior of the solar radiation, assuming that The estimate of the energy that can be generated by a photovoltaic power plant, must be defined for each day and each month of the year.

Considering that for the geographic latitude of Artemisa province, an average of 1.4 ha is required to install $1 \mathrm{MWp}$ of photovoltaic technology, the calculations of the viable areas were made, the estimate of those that have availability to install the technology, the percentage that these represent the total by municipalities and the estimate of the peak power (MWp) that could be installed. Table 3 shows the results of the analysis referred to above.

Table 3

Results of the spatial analysis by municipalities in the Artemisa province

\begin{tabular}{lcrrrrr}
\hline \multicolumn{1}{c}{ Municipalities } & $\begin{array}{c}\text { At } \\
\text { (ha) }\end{array}$ & \multicolumn{1}{c}{$\begin{array}{c}\text { Av } \\
\text { (ha) }\end{array}$} & \multicolumn{1}{c}{$\%$} & \multicolumn{1}{c}{$\begin{array}{c}\text { Ad } \\
\text { (ha) }\end{array}$} & \multicolumn{1}{c}{$\%$} & \multicolumn{1}{c}{$\begin{array}{c}\text { Pppi } \\
\text { (MWp) }\end{array}$} \\
\hline Güira de Melena & 17.700 & 2.136 & 12,1 & 43 & 0,2 & 30,5 \\
Alquizar & 19.400 & 1.456 & 7,5 & 29 & 0,2 & 20,8 \\
Bauta & 15.600 & 1.723 & 11,0 & 34 & 0,2 & 24,6 \\
San Cristóbal & 93.618 & 12.371 & 13,2 & 247 & 0,3 & 176,7 \\
Candelaria & 29.918 & 2.725 & 9,1 & 54 & 0,2 & 38,9 \\
Artemisa & 68.900 & 13.096 & 19,0 & 262 & 0,4 & 187,1 \\
Bahía Honda & 78.264 & 24.552 & 31,4 & 491 & 0,6 & 350,7 \\
S.A de los Baños & 12.600 & 2.118 & 16,8 & 42 & 0,3 & 30,3 \\
Caimito & 24.000 & 4.602 & 19,2 & 92 & 0,4 & 65,7 \\
Guanajay & 11.000 & 1.171 & 10,6 & 23 & 0,2 & 16,7 \\
Mariel & 27.100 & 4.854 & 17,9 & 97 & 0,4 & 69,3 \\
Total & 398.100 & 70.804 & 17,8 & 1.416 & 0,4 & $1.011,5$ \\
\hline
\end{tabular}

Where:

$\mathrm{Av} \rightarrow$ Viable areas.

$\mathrm{Ad} \rightarrow$ Areas with availability to be used for the installation of photovoltaic technology.

Noa, A., Pérez, A., Hechavarría, J., \& Santos, R. (2018). Energy interpretation of solar radiation affects for Artemisa province. International Journal Of Physical Sciences And Engineering (IJPSE), 2(2), 39-49. 
Pppi $\rightarrow$ Peak power possible to install.

The analysis carried out on the evaluation of the requirements of the territorial order, allowed to determine that $0.4 \%$ of the land space of the Artemisa province, can present available for the installation of photovoltaic systems and that in this area an estimated 1,011 can be installed, $5 \mathrm{MWp}$ of photovoltaic technology.

The adequate evaluation of the solar radiation of the installation site of the technology and the closest estimate to the reality of the energy that a photovoltaic power plant can generate, constitutes a necessary information to carry out the energy penetration studies of these systems to the network, being able to opportunely predict the technical conflicts that may arise and adopt the measures that opportunely guarantee the uninterrupted quality of the service.

Another of the links related to the evaluation of the solar potential and the energy estimates that derive from it is given by the same technical characteristics as the photovoltaic installations. These systems do not present moving parts, they do not make noise in their operation and they do not emit fumes of liquids and gases, so that the greater amount of technical faults that occur during the operation, are not visible nor can be detected by the sound, this It implies that the systematic technical check during the work must be done controlling the fulfillment of the daily or monthly energy generation plan, according to the type of check that is carried out.

Taking into account what has been analyzed previously, it can be defined that an inadequate evaluation of the solar potential of the site where the technology works can cause a group of undesirable impacts in the energy, economic, environmental and social order, which in the worst case can mask serious technical failures that, if not dealt with in a timely manner, can jeopardize the stability and technical status of the plant.

To carry out the evaluation of the solar potential of the province, the results developed within the framework of the SWERA project were used, drawing up the map of the annual average solar radiation in the territory.

Figure 1 shows a chromatic scale map showing the combination of information related to the viable areas of the province for the development of photovoltaic systems connected to the grid and the solar potential that affects them, where appreciate that in all the sites of the province does not affect the same level of solar radiation, so it would be an error to estimate the energy that can generate a photovoltaic power station in all locations, from the average solar potential of the territory.

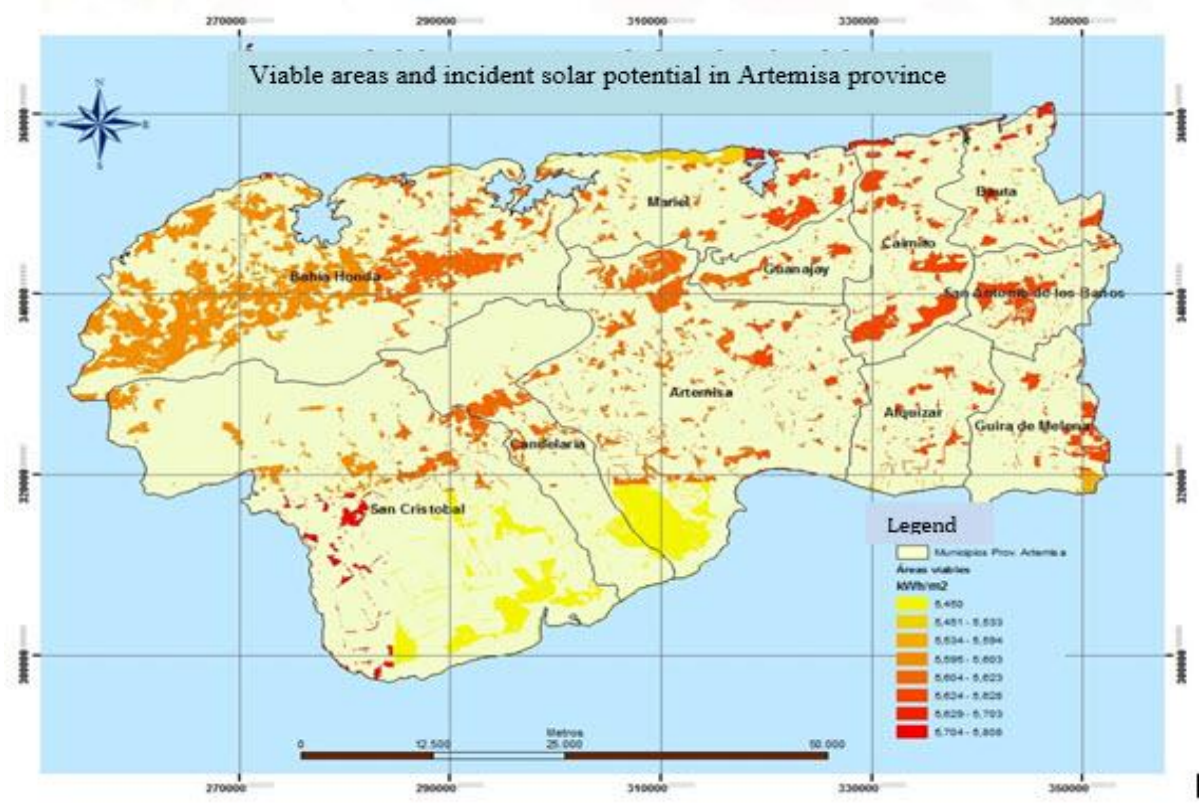

Figure 1. Viable areas and incident solar potential in Artemisa province 
The areas affected by the highest solar radiation have values of 5,808 $\mathrm{kWh} / \mathrm{m}^{2}$ per day, located in the southwest of the province in the municipality of San Cristóbal. In areas of lower radiation, the values correspond to $5,450 \mathrm{kWh} / \mathrm{m} 2$ day, located in the southern center of the territory, including part of the municipalities of San Cristóbal, Candelaria, and Artemisa. The difference between both values is a consequence of the specific climatic conditions of this territory, also influencing the central and western part of the province.

The results shown on the evaluation of the potential incident in the municipalities of the province and in each specific site, allow to perform the calculations corresponding to the estimation of the energy that a photovoltaic system can generate and constitutes a basic information for the development of the corresponding simulations to the stage of technical design of the systems that are required to be introduced.

The accomplishment of the study and punctual evaluation of the incident global solar radiation in the Artemisa province, according to the data derived from the SIGFRE Project that is developed in the CIPEL, allowed to determine as an annual average an equivalence of $5.35 \mathrm{kWh} / \mathrm{m}^{2}$ day, being able to verify that the month of greatest potential in April, the period between March to September being the month with the highest radiation and the month with the lowest month, from October to February; The most critical radiation occurs in the month of December. Table 2 shows the monthly and annual average global solar radiation by municipalities.

Table 4 shows the results by municipalities on the areas with availability to be used for the installation of photovoltaic technology, the potential peak power to be installed, the characteristic time, the possible energy to be generated in MWh / year and the oil avoided.

To know the possible energy to be generated in a year, equation 4 was used

$$
E p g=T c * P p p i
$$

Where:

Epg $\rightarrow$ Possible energy to generate (MWh / year)

To know the fuel avoided by way of energy generation, equation 5 was used.

Table 4

Possible energetic impacts in optimum inclination angle for the fixed inclined plane

\begin{tabular}{lcccrr}
\hline \multicolumn{1}{c}{ Municipalities } & $\begin{array}{c}\text { Ad } \\
\text { (ha) }\end{array}$ & $\begin{array}{c}\text { Pppi } \\
(\mathrm{MWp})\end{array}$ & $\begin{array}{c}\text { Tc } \\
(\mathrm{kWh} / \mathrm{kWp} / \mathrm{año})\end{array}$ & $\begin{array}{c}\text { Epg } \\
\text { (MWh/año) }\end{array}$ & $\begin{array}{c}\text { PPE } \\
\text { (ton/año) }\end{array}$ \\
\hline Güira de Melena & 43 & 30,5 & 1.682 & 51.301 & $12.825,3$ \\
Alquizar & 29 & 20,8 & 1.521 & 31.637 & $7.909,2$ \\
Bauta & 34 & 24,6 & 1.622 & 39.901 & $9.975,3$ \\
San Cristóbal & 247 & 176,7 & 1.556 & 274.945 & $68.736,3$ \\
Candelaria & 54 & 38,9 & 1.550 & 60.295 & $15.073,8$ \\
Artemisa & 262 & 187,1 & 1.556 & 291.128 & $72.781,9$ \\
Bahía Honda & 491 & 350,7 & 1.511 & 529.908 & $132.476,9$ \\
S .A de los Baños & 42 & 30,3 & 1.554 & 47.086 & $11.771,6$ \\
Caimito & 92 & 65,7 & 1.520 & 99.864 & $24.966,0$ \\
Guanajay & 23 & 16,7 & 1.554 & 25.952 & $6.488,0$ \\
Mariel & 97 & 69,3 & 1.555 & 107.762 & $26.940,4$ \\
Total & 1.414 & $1.011,30$ & 17.181 & 1.559 .778 & $389.944,70$ \\
\hline
\end{tabular}

Table 5 shows the results of the possible energy impacts taking into account the optimum angle for the seasonal inclination adjustment.

Noa, A., Pérez, A., Hechavarría, J., \& Santos, R. (2018). Energy interpretation of solar radiation affects for Artemisa province. International Journal Of Physical Sciences And Engineering (IJPSE), 2(2), 39-49. 
Table 5

Energetic impacts with an optimal angle with seasonal tilt adjustment

\begin{tabular}{lrrrrr}
\hline \multicolumn{1}{c}{ Municipalities } & \multicolumn{1}{c}{$\begin{array}{c}\text { Ad } \\
\text { (ha) }\end{array}$} & $\begin{array}{c}\text { Pppi } \\
\text { (MWo) }\end{array}$ & $\begin{array}{c}\text { Tc } \\
(\mathrm{kWh} / \mathrm{kWv} / \mathrm{año})\end{array}$ & $\begin{array}{c}\text { Epg } \\
(\mathrm{MWh} / \mathrm{año})\end{array}$ & \multicolumn{1}{c}{$\begin{array}{c}\text { PPE } \\
\text { (ton/año) }\end{array}$} \\
\hline Güira d Melena & 43 & 30,5 & 1.745 & $53.222,5$ & $13.305,6$ \\
Alquizar & 29 & 20,8 & 1.574 & $32.739,2$ & $8.184,8$ \\
Bauta & 34 & 24,6 & 1.681 & $41.352,6$ & $10.338,2$ \\
San Cristóbal & 247 & 176,7 & 1.613 & $285.017,1$ & $71.254,3$ \\
Candelaria & 54 & 38,9 & 1.604 & $62.395,6$ & $15.598,9$ \\
Artemisa & 262 & 187,1 & 1.620 & 303.102 & $75.775,5$ \\
Bahía Honda & 491 & 350,7 & 1.598 & $560.418,6$ & $140.104,7$ \\
S .A de los Baños & 42 & 30,3 & 1.575 & $47.722,5$ & $11.930,6$ \\
Caimito & 92 & 65,7 & 1.675 & $110.047,5$ & $27.511,9$ \\
Guanajay & 23 & 16,7 & 1.612 & $26.920,4$ & $6.730,1$ \\
Mariel & 97 & 69,3 & 1.608 & $111.434,4$ & $27.858,6$ \\
Total & 1.414 & $1.011,3$ & 17.905 & $1.634 .372,40$ & $408.593,20$ \\
\hline
\end{tabular}

With the results obtained in table 4 and 5, different energy analyzes can be performed to determine the location of possible investments in photovoltaic systems connected to the grid in the province of Artemisa, always bearing in mind that they should be installed based on the analysis of the demands that could supply.

\section{Conclusion}

The solar potential of Artemisa province does not behave uniformly throughout the territory, which is given by the influence exerted by climatic and environmental variables on it, so its definition has been important for the future development of the technologies that take advantage of solar energy.

The studies and evaluations linked to the territorial energy planning in the Artemisa province show that the territory has enough spaces that can be analyzed for the installation of photovoltaic systems connected to the electricity grid.

The evaluations carried out on the designs and technical commitments that can be assumed regarding the inclination of the photovoltaic modules show that the optimum inclination for systems with a fixed inclined plane corresponds to $25^{\circ}$. At the same time that the adjustment of seasonal inclination allows reaching a higher level of energy use than the fixed inclined plane.

\section{Conflict of interest statement and funding sources}

The authors declared that they have no competing interest. The study was financed by independent funding.

\section{Statement of authorship}

The authors have a responsibility for the conception and design of the study. The authors have approved the final article.

\section{Acknowledgments}

The authors would like to thank the editor of the journal for their valuable time and advice. 


\section{References}

1. GÁMEZ, M. R. (2011). La ordenación y la planificación de las fuentes renovables de energía en la Isla de Cuba desde una perspectiva territorial. Estudio de caso en el municipio de Guamá a partir de un Geoportal. Memoria presentada para obtener el grado de Doctora en Ciencias.

View in (Google Scholar)

2. Rodríguez M., Vázquez A. Castro M. y Isaac J. L. Introducción de sistemas fotovoltaicos autónomos (SFA) en el alumbrado público de las ciudades.

View in (HTML)

3. de Domótica-CEDOM, A. E. Instituto para la Diversificación y Ahorro de la Energía-IDAE.(2008). Cómo ahorrar energía instalando domótica en su vivienda, gane en confort y seguridad.

View in (Google Scholar)

4. De Kuyper, J. C. V. (2014). Fuentes de energía renovables y no renovables. Aplicaciones. Revista Escuela de Administración de Negocios, (77), 216-218.

View in (Google Scholar)

5. Rajiv Nair. Solar PV policies and their impacts in China and India. The Fletcher School of Law and Diplomacy, Tufts University.

View in (Article)

6. Giraudy Arafet, C. M., Massipe Cano, I., Rodríguez Rivera, R., Rodríguez Gámez, M., \& Vázquez Pérez, A. (2014). Factibilidad de instalación de sistemas fotovoltaicos conectados a red. Ingeniería Energética, 35(2), 141-148.

View in (Google Scholar)

7. Rodríguez Gámez, María. La electrificación rural en Cuba como recurso comunitario para la sustentabilidad. La Jornada Ecológica, número especial.

View in (Article)

8. Stolik Novygrod, D. (2014). La energía FV: oportunidad y necesidad para Cuba.Economía y Desarrollo, 152(2), 69-86.

View in (Google Scholar)

9. Torres Linares, C. (2017). Estudio ambiental acústico y de iluminación en el Hospital Provincial Docente Cardiocentro Ernesto Guevara de Villa Clara (Doctoral dissertation, Universidad Central" Marta Abreu" de Las Villas. Facultad de Construcciones. Departamento de Arquitectura.)

View in (Google Scholar)

10. Brunet, J. J., Capperucci, A., Chauvin, R., \& Donnadieu, B. (1997). Tandem acylation-complexation of a chlorophosphine by carbonylferrates. Journal of organometallic chemistry, 533(1), 79-81.

View in (Google Scholar)

11. Heredia Pérez Rolando, Rodríguez Gámez María, Vázquez Pérez Antonio y Martínez Linares Alejandro. Sistema de ordenamiento de las fuentes renovables de energía en Cuba. Propuesta de Geoportal de Energía. Ecosolar 39. ISSN: 1028-6004. RNPS: 2220.

View in (HTML)

12. Heredia, R. R., Montoya, S. M., López, J. D., Cuán, J. C., Gámez, M. R., Ribeaux, E., ... \& Perera, M. M. (2012). 18 años de experiencias del CIES en electrificacion rural fotovoltaica. Perspectivas.

View in (Google Scholar)

Noa, A., Pérez, A., Hechavarría, J., \& Santos, R. (2018). Energy interpretation of solar radiation affects for Artemisa province. International Journal Of Physical Sciences And Engineering (IJPSE), 2(2), 39-49.

doi:10.29332/ijpse.v2n2.142 
13. Cedeño, M. L. D., Arteaga, M. G. D., Pérez, A. V., \& Arteaga, M. L. D. (2017). Regulatory Framework for Renewable Energy Sources in Ecuador Case Study Province of Manabí. International Journal of Social Sciences and Humanities (IJSSH), 1(2), 29-42.

View in (Google Scholar)

14. Gámez, M. R., Pérez, A. V., Será, A. S., \& Ronquillo, Z. M. (2017). Renewable Energy Sources and Local Development. International Journal of Social Sciences and Humanities (IJSSH), 1(2), 10-19.

View in (Google Scholar)

15. Chilán, J. C. H., Torres, S. G. P., Machuca, B. I. F., Cordova, A. J. T., Pérez, C. A. M., \& Gámez, M. R. (2018). Social Impact of Renewable Energy Sources in the Province of Loja. International Journal of Physical Sciences and Engineering (IJPSE), 2(1), 13-25.

View in (Google Scholar) 


\section{Biography of Authors}

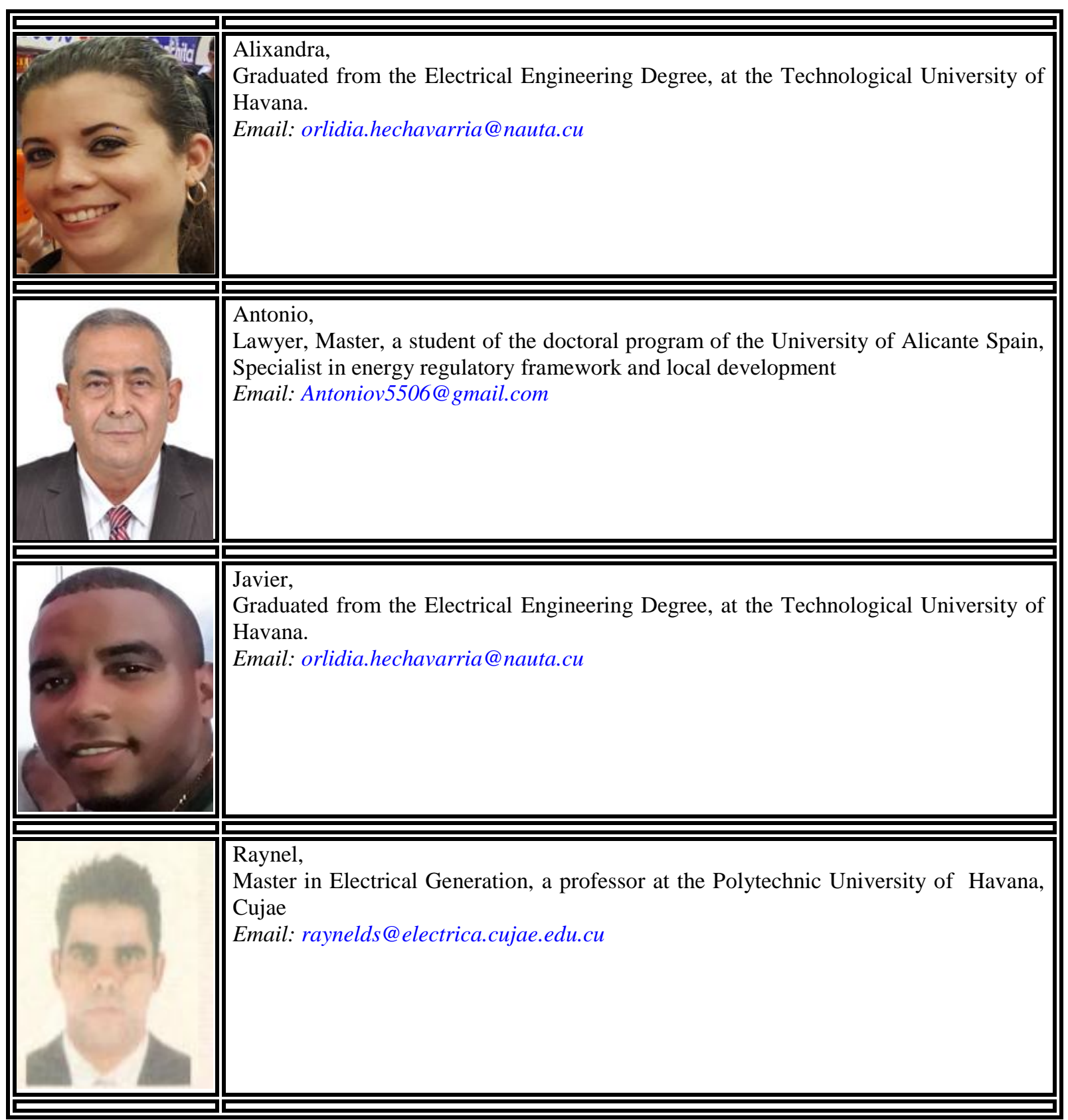

Noa, A., Pérez, A., Hechavarría, J., \& Santos, R. (2018). Energy interpretation of solar radiation affects for Artemisa province. International Journal Of Physical Sciences And Engineering (IJPSE), 2(2), 39-49. 